\title{
Efikasi Diri Siswa Dalam Pembelajaran Proyek Berbasis STEM pada Materi Termodinamika
}

\author{
Abdul Hamid Hasbullah ${ }^{1}$, Parno ${ }^{1}$, Sunaryono ${ }^{1}$ \\ ${ }^{1}$ Pendidikan Fisika-Universitas Negeri Malang
}

\section{INFO ARTIKEI}

\section{Riwayat Artikel:}

Diterima: 20-11-2019

Disetujui: 20-03-2020

\author{
Kata kunci: \\ self-efficacy; \\ project based learning, \\ thermodynamics; \\ efikasi diri; \\ termodinamika; \\ project based learning
}

\begin{abstract}
ABSTRAK
Abstract: This study aims to analyze students' self-efficacy using STEM-based Project Based Learning (PjBL) learning models. The research design uses a quasi experiment consisting of two groups, namely the experimental group and the control group. The experimental group got the treatment in the form of STEM PjBL learning while the control class used conventional learning. The self-efficacy instruments used in this study were divided into five categories. Quantitative data obtained from the study were analyzed using an independent sample t-test to see whether there were differences in self-efficacy in the two classes. The effectiveness of the treatment given in both classes was analyzed using the average Gain $(N$-Gain) value obtained by both classes. The results showed that the students' self-efficacy increased after the learning of STEM PjBL was given. In addition, the increase in the average $N$-Gain score obtained by the experimental group is better than the control group.
\end{abstract}

\begin{abstract}
Abstrak: Penelitian ini bertujuan menganalisis efikasi diri siswa menggunakan model pembelajaran Project Based Learning (PjBL) berbasis STEM. Desain penelitian menggunakan eksperimen kuasi yang terdiri dari dua kelompok yaitu kelompok eksperimen dan kelompok kontrol. Kelompok eksperimen mendapatkan treatment berupa pembelajaran PjBL STEM sedangkan kelompok kontrol menggunakan pembelajaran konvensional. Instrumen efikasi diri yang digunakan pada penelitian ini terbagi menjadi lima kategori. Data kuantitatif yang diperoleh dari penelitian dianalisis menggunakan independent sample $t$ - test untuk mengetahui ada tidaknya perbedaan efikasi diri pada kedua kelompok. Efektivitas treatment yang diberikan pada kedua kelompok dianalisis menggunakan nilai Gain $(N-$ Gain $)$ rata - rata yang dicapai kedua kelompok. Berdasarkan analisis yang dilakukan, diperoleh bahwa efikasi diri siswa mengalami kenaikan setelah pembelajaran PjBL STEM diberikan. Selain itu, peningkatan skor rata - rata $N$-Gain yang diperoleh kelompok eksperimen lebih baik dibandingkan kelompok kontrol.
\end{abstract}

Alamat Korespondensi:

Abdul Hamid Hasbullah

Pendidikan Fisika

Universitas Negeri Malang

Jalan Semarang 5 Malang

E-mail: parno.fmipa@um.ac.id

Menurut Bandura (1995), efikasi diri merupakan tujuan dari seseorang dalam mengambil keputusan bagi dirinya sendiri. Keyakinan ini dapat mempengaruhi keputusan seseorang pada berapa banyak usaha yang harus mereka keluarkan untuk mencapai tujuan yang hendak dicapai, berapa lama waktu yang dibutuhkan dalam mengatasi masalah, dan bagaimana seseorang bereaksi terhadap kegagalan. Penelitian tentang efikasi diri dalam pembelajaran memberikan kesempatan yang lebih baik dalam memahami fenomena yang terjadi selama proses pembelajaran (Andersen et al., 2004). Terdapat kaitan antara efikasi diri terhadap keberhasilan siswa dalam belajar (Chen and Pajares, 2010; Cheung, 2015; Wardhani, 2015). Selain itu, Tuan et al., (2005) dalam penelitiannya mengemukakan bahwa efikasi diri, tujuan belajar, dan strategi pembelajaran merupakan domain penting yang mampu memotivasi siswa dalam pembelajaran sains.

Model pembelajaran yang mampu meningkatkan keaktifan dan dapat menumbuhkan kreativitas siswa salah satunya yaitu Project Based Learning (PjBL) (Thomas, 2000). Tujuan dari PjBL adalah untuk memastikan semua siswa mempelajari mata pelajaran secara terintegrasi (Hamurcu, 2003). Secara umum, PjBL didefinisikan sebagai upaya belajar siswa dalam periode waktu tertentu untuk mencapai tujuan secara berkelompok melalui partisipasi aktiv semua siswa. Tujuan utama PjBL adalah untuk membantu siswa bertanggung jawab atas pembelajaran mereka sendiri dan mendukung para siswa dalam bekerja sama secara kolaboratif (Saban, 2000; Simkins et al., 2002). Dalam PjBL, belajar berarti bahwa siswa sedang merekonstruksi pengetahuan intelektual mereka. Mereka membangun pengetahuan mereka sendiri melalui pengalaman kehidupan nyata.

Selain itu, mereka dapat mandiri selama proses pembelajaran dan dapat mengambil keputusan secara mandiri. Situasi semacam ini dapat meningkatkan motivasi dan keterampilan mereka (Solomon, 2003). Beberapa penelitian terdahulu 
menunjukkan bahwa PjBL mampu memberikan kontribusi positif terhadap prestasi akademik siswa (Cengizhan, 2007; Kanter and Konstantopoulos, 2010; Shih et al., 2010), menumbuhkan pembelajaran bermakna dalam pembelajaran sains (Krajcik et al., 2008; Kanter, 2010), meningkatkan pembelajaran individu siswa (Chang and Tseng, 2011), menumbuhkan sikap positif siswa dalam pembelajaran sains (Tortop and Ozek, 2013), dan meningkatkan kepribadian akademik siswa (Korkmaz and Kaptan, 2002). Sementara itu Hung et al., (2012) menyatakan bahwa PjBL yang dikombinasikan dengan teknologi efektif dalam meningkatkan motivasi siswa dalam belajar sains, meningkatkan prestasi belajar, dan kemampuan pemecahan masalah siswa.

Pembelajaran saat ini hendaknya tidak terlepas dari perkembangan zaman melalui kombinasi PjBL dengan bidang lain salah satunya yaitu dengan mengintegrasikan Sains, Teknologi, Engineering, dan Matematika (STEM). Menurut Kim dan Cho (2015) integrasi STEM ke dalam pembelajaran sains akan dapat membuat siswa lebih sadar dalam mengkaitkan pendidikan di sekolah dengan kehidupan nyata. Selain itu, Bilgin et al., (2015) juga berpendapat bahwa integrasi STEM ke dalam PjBL mampu membuat siswa lebih sadar terhadap keyakinan mereka sendiri serta lebih bersemangat dalam aktivitas belajarnya. Integrasi STEM dalam PjBL diharapkan mampu menciptakan pembelajaran yang bermakna bagi siswa secara sistematis melalui integrasi konsep, pengetahuan, dan keterampilan. Manfaat yang muncul dari integrasi STEM yaitu siswa memiliki keterampilan pemecahan masalah yang lebih baik, inovator, penemu, independen, berpikir logis, serta melek terhadap perkembangan teknologi (Morrison dalam Stohlmann et al., 2012).

\title{
METODE
}

Pada penelitian ini, digunakan metode kuasi eksperimen yang terbagi atas dua kelompok yaitu kelompok eksperimen dan kelompok kontrol. Kelompok eksperimen diberikan treatment berupa pembelajaran Project Based Learning berbasis STEM (PjBL STEM) sedangkan kelompok kontrol diberi treatment berupa pembelajaran konvensional. Tempat penelitian di SMA Negeri 1 Kraksaan pada semester II Tahun Ajaran 2018/2019. Desain penelitian yang digunakan ditunjukkan pada tabel 1.

Tabel 1. Desain Eksperimen Kuasi tipe pre \& post test control group design (Creswell, 2012)

\begin{tabular}{ccc}
\hline Presurvey & Treatment & Postsurvey \\
\hline $\mathrm{O}_{1}$ & $\mathrm{X}$ & $\mathrm{O}_{2}$ \\
$\mathrm{O}_{1}$ & $\mathrm{Y}$ & $\mathrm{O}_{2}$ \\
\hline
\end{tabular}

\author{
Keterangan: \\ X : Pembelajaran PjBL Berbasis STEM pada kelompok Eksperimen \\ Y : Pembelajaran konvensional pada kelompok Kontrol \\ $\mathrm{O}_{1} \quad$ : Presurvey \\ $\mathrm{O}_{2} \quad$ : Postsurvey
}

Subjek penelitian yaitu kelompok XI MIPA 1 (kelompok kontrol) sebanyak 30 siswa dan kelompok XI MIPA 3 (kelompok eksperimen) sebanyak 35 siswa. Instrumen yang digunakan terdiri dari Silabus, RPP, LKS, dan Angket efikasi diri. Silabus dan RPP yang digunakan mengacu pada pembelajaran Kurikulum 2013 yang digunakan oleh sekolah tempat penelitian dilakukan. RPP dan LKS yang digunakan disusun berdasarkan model PjBL STEM pada materi Termodinamika yang sebelumnya telah divalidasi oleh dosen ahli.

Angket efikasi diri yang digunakan menggunakan angket efikasi diri oleh Lin dan Tsai (2013) yang merupakan adopsi dari angket efikasi diri dari Baldwin et al., (1999). Angket efikasi diri terdiri dari 28 butir soal dengan lima tingkat keyakinan yaitu tidak yakin, kurang yakin, cukup yakin, yakin, dan sangat yakin. Lin dan Tsai juga membagi angket efikasi diri menjadi lima kategori yaitu (1) Efikasi diri dalam mengkaitkan konsep fisika dengan konsep sains lainnya, (2) Efikasi diri hubungannya dalam ketrampilan yang komplek seperti keterampilan pemecahan masalah dan berpikir kritis, (3) Efikasi diri dalam bidang psikomotorik dan kinerjanya dalam bekerja di laboratorium fisika, (4) Efikasi diri dalam menerapkan konsep sains yang dipahami dan teknologi dalam penerapan sehari-hari, (5) efikasi diri dalam berdiskusi dan mengkomunikasikan pengetahuan fisika dengan teman sekelompok atau orang lain dalam pembelajaran sains. Sebelum digunakan dalam penelitian, uji empiris dilakukan untuk melihat validitas dan reliabilitas dari instrument angket efikasi diri. Dari hasil uji empiris yang dilakukan diketahui bahwa instrument angket efikasi diri dinyatakan valid dan reliabel.

Data kuantitatif hasil penelitian dianalisa menggunakan uji statistik independent sample $t$ - test untuk melihat ada tidaknya perbedaan skor rata-rata pada kedua kelompok. Selanjutnya, efektifitas dari treatment yang diberikan dianalisa menggunakan nilai Gain $(N-$ Gain) rata=rata yang diperoleh kedua kelompok. Selain itu, akan dilihat pula peningkatan skor rata-rata efikasi diri pada masing-masing kelima kriteria efikasi menggunakan $N$ - Gain rata - rata pada kelima kriteria efikasi. 
HASIL

Efikasi diri siswa diukur menggunakan angket efikasi diri pada kelompok eksperimen dan kelompok kontrol. Angket efikasi diri diberikan pada siswa di kelompok eksperimen sebelum dan setelah pembelajaran PjBL STEM diberikan dan pada siswa di kelompok kontrol sebelum dan setelah pembelajaran konvensional diberikan. Selanjutnya, data yang telah diperoleh dianalisis secara deskriptif dan hasilnya ditampilkan pada tabel 1.

Tabel 1. Statistik Deskriptif Presurvey dan Postsurvey Efikasi Diri Siswa

\begin{tabular}{ccccc}
\hline Data & \multicolumn{2}{c}{ Kelompok Eksperimen } & \multicolumn{2}{c}{ Kelompok Kontrol } \\
\cline { 2 - 5 } & Presurvey & Postsurvey & Presurvey & Postsurvey \\
\hline Skor terendah & 26,43 & 69,29 & 22,14 & 47,14 \\
Skor tertinggi & 45,71 & 81,43 & 36,43 & 66,43 \\
\hline Rerata & 35,53 & 76,26 & 32,50 & 58,07 \\
\hline Jumlah data & \multicolumn{3}{c}{35} & \multicolumn{3}{c}{30} \\
\hline
\end{tabular}

Sebelum melakukan uji independent sample $t$ - test pada data postsurvey efikasi kedua kelompok, terlebih dahulu kedua data diuji normalitas dan homogenitasnya untuk memastikan bahwa data dapat diuji menggunakan statistik parametrik. Hasil uji normalitas dan homogenitas postsurvey pada kedua kelompok disajikan pada tabel 2 dan 3.

Tabel 2. Hasil Uji Normalitas Postsurvey Efikasi Diri

\begin{tabular}{lcc}
\hline Kelompok Data Penelitian & $\begin{array}{c}\text { Kolmogorov - Smirnov } \\
\text { Sig. }\end{array}$ & Keterangan \\
\hline Kelompok eksperimen & .087 & normal \\
Kelompok kontrol & .200 & normal \\
\hline
\end{tabular}

Tabel 3. Hasil Uji Homogenitas Postsurvey Efikasi Diri

\begin{tabular}{cc}
\hline $\begin{array}{c}\text { Levene Test } \\
\text { Sig. }\end{array}$ & Keterangan \\
\hline .163 & homogen \\
\hline
\end{tabular}

Hasil uji statistik menggunakan independent sample $t$ - test pada kedua kelompok menghasilkan signifikansi sebesar 0.00 yang lebih kecil dari nilai signifikansi alfa sebesar 0.05. Dari hasil uji statistik dapat disimpulkan bahwa terdapat perbedaan efikasi diri siswa pada kedua kelompok penelitian. Nilai Gain rata - rata pada kedua kelompok diperoleh sebesar 63,05 untuk kelompok eksperimen dan 37,79 untuk kelompok kontrol. Berdasarkan tafsiran efektivitas N-Gain pada tabel 4, menunjukkan bahwa pembelajaran PjBL STEM yang diberikan pada kelompok eksperimen cukup efektif dalam meningkatkan efikasi diri siswa, sedangkan pembelajaran konvensional yang diberikan pada kelompok kontrol tidak efektif dalam meningkatkan efikasi diri siswa.

Tabel 4. Kategori Tafsiran Efektivitas N-Gain

\begin{tabular}{cc}
\hline Presentase (\%) & Tafsiran \\
\hline$<40$ & Tidak efektif \\
$40-55$ & Kurang efektif \\
$56-75$ & Cukup efektif \\
$>76$ & Efektif
\end{tabular}

Perubahan skor N-Gain rata - rata pada kelima kriteria efikasi diri, ditunjukkan pada tabel 5 dan 6 .

Tabel 5. Peningkatan N-Gain Rata - Rata Kelima Kriteria Kelompok Eksperimen

\begin{tabular}{cccc}
\hline & Rata-rata skor presurvey & Rata-rata skor postsurvey & $\boldsymbol{N}$-Gain rata-rata (\%) \\
\hline Kriteria 1 & 27,86 & 72,57 & $61,98 \%$ \\
Kriteria 2 & 36,00 & 75,71 & $62,05 \%$ \\
Kriteria 3 & 41,28 & 81,86 & $69,11 \%$ \\
Kriteria 4 & 34,64 & 74,43 & $60,88 \%$ \\
Kriteria 5 & 37,33 & 78,00 & $64,90 \%$ \\
\hline
\end{tabular}


Tabel 6. Peningkatan N-Gain Rata - Rata Kelima Kriteria Kelompok Kontrol

\begin{tabular}{cccc}
\hline & Rata-rata skor presurvey & Rata-rata skor postsurvey & N-Gain rata-rata (\%) \\
\hline Kriteria 1 & 27,33 & 52,50 & $34,64 \%$ \\
Kriteria 2 & 32,44 & 57,89 & $37,67 \%$ \\
Kriteria 3 & 37,17 & 65,33 & $44,82 \%$ \\
Kriteria 4 & 31,92 & 55,50 & $34,64 \%$ \\
Kriteria 5 & 33,67 & 60,56 & $40,54 \%$ \\
\hline
\end{tabular}

\section{PEMBAHASAN}

Pada penelitian ini, efikasi diri siswa dibagi menjadi lima kriteria. Kelima kriteria tersebut, yaitu (1) efikasi diri dalam mengkaitkan konsep fisika dengan konsep sains lainnya, (2) efikasi diri dalam menilai kemampuan siswa dalam ketrampilan yang komplek seperti keterampilan pemecahan masalah dan berpikir kritis, (3) efikasi diri dalam menilai kemampuan siswa dalam bidang psikomotorik dan kinerjanya dalam bekerja di laboratorium fisika, (4) efikasi diri dalam menerapkan konsep sains yang telah dipahami dalam teknologi yang digunakan dalam keseharian, dan (5) efikasi diri dalam berdiskusi dan mengomunikasikan pengetahuan fisika dengan teman sekelompok atau orang lain dalam pembelajaran sains. Skor pencapaian siswa pada kelima kriteria efikasi diri dapat dilihat pada tabel 5 dan 6. Peningkatan skor $N$-Gain rata - rata tertinggi dicapai oleh kriteria 3 dengan peningkatan skor sebesar 69,11\%. Disusul oleh kriteria 5 dengan peningkatan skor sebesar $64,90 \%$. Selanjutnya, peningkatan skor kriteria 2 dan kriteria 1 dengan peningkatan skor masing-masing sebesar 62,05\% dan $61,98 \%$. Dan terakhir, peningkatan skor terendah dicapai oleh kriteria 4 dengan peningkatan skor sebesar $60,88 \%$.

Efikasi diri siswa pada kriteria 1 berkaitan dengan bagaimana siswa mampu mengkaitkan antara konsep fisika yang dipelajari di dalam kelompok dan berusaha menghubungkan pemahaman yang mereka peroleh dengan konsep dalam bidang ilmu sains lainnya. Peningkatan skor efikasi diri siswa pada kriteria 1 sebesar $61,98 \%$ yang merupakan peningkatan yang cukup signifikan jika dibandingkan dengan kriteria 1 pada kelompok kontrol. Peningkatan efikasi diri siswa pada penelitian ini sejalan dengan penelitian sebelumnya yang dilakukan oleh Bilgin et al., (2015) yang menemukan bahwa pembelajaran proyek mampu meningkatkan kepercayaan diri dalam memahami konsep.

Pembelajaran proyek berbasis STEM merupakan pembelajaran yang berusaha menghubungkan antara satu bidang sains dengan bidang sains lainnya (Bybee, 2010). PjBL STEM mengurangi hambatan antar tiap disiplin ilmu dan mengitegrasikannya dalam satu paradigma pembelajaran terpadu dan menggabungkan konsep akademik kedalam suatu pembelajaran dunia nyata (Morrison, 2006). Masalah dalam dunia nyata yang disajikan oleh guru memungkinkan siswa untuk merencanakan, merancang, dan mengimplementasikan solusi dalam bentuk proyek penelitian dimana hal ini merupakan jawaban dari permasalahan yang diberikan. Para siswa juga dituntut tidak hanya kreatif dalam bekerja sekaligus juga mampu bekerja sama dalam tim dan mampu mengkaitkan antara solusi yang ditawarkan dengan konsep secara ilmiah.

Menurut Morrison (2006), PjBL STEM menjadikan siswa memiliki empat karakter. Pertama, sebagai problem sover yaitu mampu mendefinisikan, merancang, mengumpulkan serta mengelompokkan data kemudian menarik kesimpulan dari data tersebut dan menerapkan pemahamannya dalam situasi terkini. Kedua, sebagai innovator yaitu kreatif dalam menggunakan sains, teknologi, matematika, dan engineering dalam dunia nyata. Ketiga, sebagai inventor mandiri yaitu mampu menggunakan inisiatif dan motivasi diri dalam menyusun rencana, mengembangkan, dan bekerja dalam kerangka waktu yang ditentukan. Keempat, sebagai pemikir logis yaitu menerapkan proses pemikiran yang logis dan rasional dari sains, matematika, dan desain teknik dalam inovasi teknologi.

Proses dalam mengembangkan empat karakter tersebut terjadi pada saat siswa membuat dan mengembangkan sebuah proyek dalam memecahkan permasalahan yang disajikan oleh guru. Siswa mengajukan solusi, memilah solusi terbaik, selanjutnya membuat dan menguji prototipe dari proyek yang telah dibuat. Dalam pembuatan proyek, para siswa bekerja di laboratorium sekolah maupun di rumah dengan peralatan-peralatan sains dan teknik misalnya jangka sorong untuk mengukur ketebalan dan diameter bahan yang akan digunakan dalam membuat proyek, gelas ukur yang digunakan untuk mengukur volume air saat menguji prototipe proyek, termometer untuk mengukur suhu, dll. Akhirnya, siswa melakukan uji coba prototipe proyek setelah proyek selesai dibuat. Uji coba prototipe proyek dilakukan di sekolah dan dilakukan didepan kelompok lainnya. Para anggota kelompok kemudian mempresentasikan hasil kerjanya mulai dari awal hingga proyek selesai dibuat sambil juga mengutarakan kelebihan dan kekurangan dari proyek yang mereka buat.

Proses pembuatan proyek secara tidak langsung telah melatih kemampuan berpikir kritis serta kreativitas siswa (Capraro et al., 2013). Selain itu, para siswa juga mulai membiasakan diri dalam menggunakan peralatan-peralatan laboratorium yang mungkin sebelumnya tidak pernah mereka pakai atau tidak mereka ketahui fungsi dan kegunaannya. Meningkatnya kepercayaan diri siswa dalam kriteria 2 dan kriteria 3 efikasi diri tampak dari meningkatnya skor $N$-Gain rata-rata efikasi diri siswa pada kriteria 2 sebesar $62,05 \%$ dan kriteria 3 sebesar 69,11\%. Temuan ini sejalan dengan hasil penelitian lainnya bahwa PjBL STEM dapat meningkatkan kreativitas siswa (Arisanti et al., 2016; Sumarni et al., 2016; Kristiani et al., 2017; Lestari et al., 2018; Munawaroh et al., 2018). 
Problem yang disajikan oleh guru merupakan permasalahan dalam dunia nyata. Melalui problem yang disajikan, para siswa dituntut untuk mengajukan serta mengembangkan solusi yang kreatif dan nyata sebagai bentuk dari kedalaman berpikir tingkat tinggi mereka (berpikir kritis dan berpikir kreatif). Seringkali siswa tidak dapat mengkaitkan antara konsep yang di pelajari dengan permasalahan dunia nyata. Melalui PjBL STEM, siswa didorong untuk mendesain, mengembangkan, dan memanfaatkan teknologi serta mengasah kemampuan kognitif dan afektif dan mampu mengaplikasikannya dalam kehidupan nyata (Kapila and Iskander, 2014). Peningkatan skor rata-rata efikasi diri sebesar 60,88\% pada kriteria 4 menunjukkan bahwa PjBL STEM dalam pembelajaran mampu meningkatkan kepercayaan diri siswa dalam menerapkan konsep sains yang siswa pelajari dalam kehidupan sehari-hari.

Mampu berkomunikasi dengan baik merupakan ciri dari seseorang yang menguasai dan memahami pengetahuan. Kemampuan berkomunikasi hendaknya selalu dilatih dan dikuasai oleh setiap orang (Widiani et al., 2016). Dalam PjBL STEM, kemampuan berkomunikasi ini menjadi bagian penting dan tak terpisahkan dari serangkaian proses pembelajaran mulai dari awal pembuatan proyek sampai akhir proyek itu dilaksanakan. Peningkatan skor $N$-Gain rata-rata efikasi diri siswa pada kriteria 5 sebesar 64,90\% menunjukkan bahwa PjBL STEM memiliki pengaruh yang cukup signifikan dalam keyakinan berkomunikasi siswa. Dalam pembuatan proyek, siswa berinteraksi dengan siswa lainnya sehingga terjadi proses saling belajar dan saling bertukar informasi antar sesama siswa. Dalam pembuatan proyek, siswa juga saling berinteraksi tidak hanya bertukar ide tentang pembuatan proyek, namun juga bertukar ide tentang konsep atau teori yang ada pada peralatan yang mereka gunakan dan buat. Proses interaksi antar sesama siswa dan lingkungan yang mendukung mereka dalam proses belajar memiliki pengaruh dalam meningkatkan efikasi diri siswa (Schunk et al., 2012).

Pembelajaran proyek berbasis STEM telah terbukti mampu meningkatkan efikasi diri siswa. Meskipun peningkatan skor pada kelima kriteria efikasi diri besarnya berbeda namun tetap memiliki dampak dan pengaruh positif bagi siswa. Namun demikian, masih terdapat kelemahan dan kendala dalam penelitian ini diantaranya (1) Dalam pembuatan proyek, diperlukan biaya dan waktu yang tidak sedikit sehingga persiapan yang kurang matang dan waktu yang terbatas akan membuat proyek yang dibuat tidak maksimal dan cenderung asal - asalan (2) Pembuatan proyek tidaklah mudah sehingga apabila siswa merasa tidak menemukan solusi atau jalan keluar dari permasalahan tersebut maka kepercayaan diri siswa justru menjadi semakin berkurang (3) Komposisi siswa dalam setiap kelompok sangat menentukan keberhasilan dalam pembuatan proyek. Kelompok yang terdiri dari siswa dengan kemampuan sama atau setara cenderung menghambat keberhasilan dalam pembuatan proyek dan cenderung akan menurunkan tingkat efikasi diri siswa.

Berdasarkan kekurangan dari penelitian ini, maka pada penelitian selanjutnya perlu memperhatikan hal-hal berikut (1) perlu persiapan matang, (2) perlu waktu bimbingan yang lebih dengan memanfaatkan teknologi, misalnya grup whatsapp, dan (3) penentuan kelompok perlu memperhatikan komposisi siswa.

\section{SIMPULAN}

Dari hasil analisis data pada penelitian ini dapat ditarik kesimpulan bahwa model pembelajaran proyek berbasis STEM dapat meningkatkan efikasi diri siswa. Siswa merasa yakin dapat mengkaitkan konsep dalam tiap cabang ilmu sains yang dipelajarinya. Siswa juga memiliki keyakinan dalam menggunakan peralatan fisika maupun peralatan laboratorium lainnya. Aplikasi konsep sains dibidang penerapan teknologi dalam keseharian, keyakinan siswa pula mengalami peningkatan yang tercermin dari kemampuan berpikir kritis maupun berpikir kreatif. Keyakinan siswa juga mengalami peningkatan dalam mengomunikasikan pengetahuan yang mereka pahami pada orang lain.

Sebelum pembelajaran proyek berbasis STEM dilaksanakan, sebaiknya guru pembimbing perlu mempersiapkan terlebih dahulu pembelajaran yang akan dilaksanakan dengan sebaik-baiknya. Persiapan sangat diperlukan mengingat model pembelajaran proyek berbasis STEM memerlukan waktu serta peralatan pendukung yang tidak mudah diperoleh. Selain itu, sikap mental siswa perlu dilatih dan dibiasakan karena mereka tidak hanya bekerja dan belajar secara perorangan akan tetapi berkolaborasi dalam kelompok yang notabene memiliki karakter dan kemampuan beragam. Bimbingan belajar di luar jam sekolah melalui media teknologi, seperti grup whatsapp yang dimonitor langsung oleh guru akan sangat membantu kesuksesan pembuatan proyek.

\section{DAFTAR RUJUKAN}

Andersen, A.M., Dragsted, S., Evans, R.H., Sørensen, H. (2004). The Relationship Between Changes in Teachers' Self-Efficacy Beliefs and The Science Teaching Environment of Danish First-Year Elementary Teachers. Journal of Science Teacher Education, 15, 25-38.

Arisanti, W. O. L., Sopandi, W., \& Widodo, A. (2016). Analisis Penguasaan Konsep dan Keterampilan Berpikir Kreatif Siswa SD Melalui Project Based Learning. EDUHUMANIORA: Jurnal Pendidikan Dasar 8, 82-95.

Baldwin, J. A., Ebert-May, D., Burns, D. J. (1999). The Development of a College Biology Self-Efficacy Instrument for Nonmajors. Science Education, 83, 397-408.

Bilgin, I., Karakuyu, Y., Ay, Y. (2015). The Effects of Project Based Learning On Undergraduate Students Achievement and Self-Efficacy Beliefs Towards Science Teaching. Eurasia Journal of Mathematics, Science \& Technology Education, 11, $469-477$.

Bybee, R. (2010). Advancing STEM Education: A 2020 Vision. Technology and Engineering Teacher, 70 (6), 30-35. 
Capraro, R. M., Capraro, M. M., Morgan, J. R. (2013). STEM Project-Based Learning: An Integrated Science, Technology, Engineering, and Mathematics (STEM) Approach. Springer Science \& Business Media.

Cengizhan, S. (2007). The Effects of Project Based and Computer Assisted Instructional Designs on Those Students Who Have depended, Independed and Cooperative Learning Styles, Academic Achievement and Learning Retention. Journal of Turkish Educational Sciences 5, 377-401.

Chang, C. C., Tseng, K. H. (2011). Using a Web-Based Portfolio Assessment System to Elevate Project-Based Learning Performances. Interactive Learning Environments 19, 211-230.

Chen, J. A., Pajares, F. (2010). Implicit Theories of Ability of Grade 6 Science Students: Relation to Epistemological Beliefs and Academic Motivation and Achievement in Science. Contemporary Educational Psychology, 35, $75-87$.

Cheung, D. (2015). The Combined Effects of Classroom Teaching and Learning Strategy Use on Students Chemistry SelfEfficacy. Research in Science Education, 45, 101-116.

Creswell, J. W. (2012). Educational Research: Planning, Conducting and Evaluating Quantitative and Qualitative Research . Boston: Edwards Brothers. Inc.

Hake, R. R. (1999). Interactive-Engagement Versus Traditional Methods: A Sixthousand-Student Survey of Mechanics Test Data for Introductory Physics Courses. American Journal of Physics, 66(1), 64-74. https://doi.org/10.1119/1.18809

Hamurcu, H. (2003). Project Approach to Teaching Science in Preschool Education. Eurasian Journal of Educational Researcher, 13, 66-72.

Hung, C. M., Hwang, G. J., \& Huang, I. (2012). A Project-Based Digital Storytelling Approach for Improving Students' Learning Motivation, Problem-Solving Competence and Learning Achievement. Journal of Educational Technology \& Society $15,368-379$.

Kanter, D. E. (2010). Doing the Project and Learning the Content: Designing Project-Based Science Curricula for Meaningful Understanding. Science Education, 94, 525-551.

Kanter, D. E., \& Konstantopoulos, S. (2010). The Impact of a Project-Based Science Curriculum on Minority Student Achievement, Attitudes, and Careers: The Effects of Teacher Content and Pedagogical Content Knowledge and InquiryBased Practices. Science Education 94, 855-887.

Kapila, V., Iskander, M. (2014). Lessons Learned from Conducting a K-12 Project to Revitalize Achievement by Using Instrumentation in Science Education. Journal of STEM Education 15.

Kim, M. K., Cho, M. K. (2015). Design and Implementation of Integrated Instruction of Mathematics and Science in Korea. Eurasia Journal of Mathematics, Science \& Technology Education, 11.

Korkmaz, H., Kaptan, F. (2002). The Effects of Project-Based Learning on Elementary School Students' Academic Achievement, Academic Self-Concepts and Study Time in Science Education. Hacettepe Üniversitesi Eğitim Fakültesi Dergisi-Hacettepe University. Journal of Education 22, 91-97.

Krajcik, J., McNeill, K. L., \& Reiser, B. J. (2008). Learning-Goals-Driven Design Model: Developing Curriculum Materials That Align with National Standards and Incorporate Project-Based Pedagogy. Science Education, 92, 1-32.

Kristiani, K. D., Mayasari, T., \& Kurniadi, E. (2017). Pengaruh pembelajaran STEM-PjBL terhadap Keterampilan Berpikir Kreatif, in: Prosiding SNPF (Seminar Nasional Pendidikan Fisika). pp. 266-274.

Lestari, T. P., Sarwi, S., \& Sumarti, S. S. (2018). STEM-Based Project Based Learning Model to Increase Science Process and Creative Thinking Skills of $5^{\text {th }}$ Grade. Journal of Primary Education 7, 18-24.

Lin, T.-J., Tsai, C. C. (2013). A Multi-Dimensional Instrument for Evaluating Taiwanese High School Students Science Learning Self-Efficacy in Relation to Their Approaches to Learning Science. International Journal of Science and Mathematics Education 11, 1275-1301.

Munawaroh, R., Rusilowati, A., \& Fianti, F. (2018). Improving Scientific Literacy and Creativity through Project Based Learning. Physics Communication 2, 85-93.

Schunk, D. H., Meece, J. R., Pintrich, P. R. (2012). Motivation in Education: Theory, Research, and Applications. Pearson Higher Ed.

Shih, J. L., Chuang, C. W., Hwang, G. J. (2010). An Inquiry-Based Mobile Learning Approach to Enhancing Social Science Learning Effectiveness. Journal of Educational Technology \& Society 13, 50-62.

Stohlmann, M., Moore, T. J., Roehrig, G. H. (2012). Considerations for Teaching Integrated STEM Education. Journal of PreCollege Engineering Education Research (J-PEER) 2, 4.

Sumarni, W., Wardani, S., Sudarmin, S., \& Gupitasari, D. (2016). Project Based Learning (PBL) to Improve Psychomotoric Skills: A Classroom Action Research. Jurnal Pendidikan IPA Indonesia 5, 157-163.

Tuan, H. L., Chin, C. C., Shieh, S. H. (2005). The Development of a Questionnaire to Measure Students' Motivation Towards Science Learning. International Journal of Science Education, 27, 639-654.

Wardhani, P. A. (2015). Efikasi Diri dan Pemahaman Konsep IPA dengan Hasil Belajar Ilmu Pengetahuan Alam Siswa Sekolah Dasar Negeri Kota Bengkulu. Jurnal Pendidikan Dasar, 6(1), 58-67.

Widiani, T., Rifat, M., \& Ijuddin, R. (2016). Penerapan Pendekatan Saintifik dan Pengaruhnya terhadap Kemampuan Komunikasi Matematis dan Berpikir Kreatif Siswa. Jurnal Pendidikan dan Pembelajaran Khatulistiwa, 5(1), 1-14. 